\title{
Potensi Tumbuhan Melastoma malabathricum L. Sebagai Bahan Antibakteri Salmonellosis
}

\section{Ethanol Extracts of Melastoma malabathricum L. Leaves Potential as anti- bacterial agent on Salmonella}

\author{
Mutia Handayani *), Orryani Lambui dan I Nengah Suwastika \\ Lab. Bioteknologi, Jurusan Biologi FMIPA Untad \\ Kampus Bumi Tadulako Jl. Soekarno-Hatta Km.9 Palu, Sulawesi Tengah 94118
}

\begin{abstract}
The research about ethanol extracts of Melastoma malabathricum L. Leaves potential as antibacterial agent on Salmonella was conducted in September until December 2016. The purpose of research to describe the morphology of plants M. malabathricum L. from the village of Lero, determine the effectiveness of $M$. malabathricum L. leaf extract and concentration effective in inhibiting the growth of bacteria Salmonella typhi. Survey methods for obtaining plants, descriptive method is used for determination of plants and experimental methods with completely randomized design (CRD) with 6 treatments and 3 repetitions. Treatment by administration leaf extract concentration of $10 \%, 20 \%, 40 \%$, and $60 \%$ and $2 \%$ antibiotic amoxicillin as a positive control and $\mathrm{Na}-\mathrm{CMC} 1 \%$ as a negative control. The results showed that plant M. malabathricum L. from the village of Lero is a plant similar to the plant described by Van Valkenburg and Bunyapraphatsara (2002), with morphological differences in plants M. malabatricum L. include plant height and leaf size. In the test of inhibition, leaf extract concentration of $60 \%$ resulted in inhibition zone with the greatest diameter is $20,6 \mathrm{~mm}$, this suggests that M. malabathricum L. leaf extracts have inhibitory better than the leaf extract concentration of $10 \%, 20 \%$ and $40 \%$.
\end{abstract}

Keywords: Melastoma malabathricum L., Antibacterial, Salmonellosis.

\begin{abstract}
ABSTRAK
Penelitian tentang potensi tumbuhan Melastoma malabathricum L. sebagai bahan antibakteri Salmonellosis telah dilaksanakan pada bulan September sampai Desember 2016. Tujuan penelitian ini yaitu a) untuk mendeskripsikan morfologi tumbuhan M. malabathricum L. yang berasal dari Desa Lero, b) mengetahui efektivitas ekstrak daun M. malabathricum L. dalam menghambat pertumbuhan bakteri Salmonella typhi dan c) mengetahui konsentrasi yang efektif dalam menghambat pertumbuhan bakteri S. typhi. Metode survei digunakan untuk memperoleh tumbuhan, metode deskriptif digunakan untuk determinasi tumbuhan dan metode eksperimental untuk melihat kemampuan antibakteri yang disusun berdasarkan model Rancangan Acak Lengkap (RAL) dengan 6 perlakuan dan 3 kali ulangan. Perlakuan dengan pemberian konsentrasi ekstrak daun 10\%, 20\%, 40\%, 60\% serta antibiotik amoxicillin $2 \%$ sebagai kontrol positif dan Na-CMC $1 \%$ sebagai kontrol negatif. Hasil penelitian menunjukkan bahwa tumbuhan M. malabathricum L. yang berasal dari Desa Lero merupakan tumbuhan yang sejenis dengan tumbuhan yang dideskripsikan oleh Van Valkenburg and Bunyapraphatsara (2002), dengan perbedaan morfologi pada tumbuhan M. malabatricum L. meliputi tinggi batang dan ukuran daun. Pada uji daya hambat, konsentrasi ekstrak daun $60 \%$ menghasilkan zona hambat dengan diameter paling besar yaitu $20,6 \mathrm{~mm}$, hal ini menunjukkan bahwa ekstrak daun M. malabathricum L. memiliki daya hambat yang lebih baik dibandingkan dengan konsentrasi ekstrak daun $10 \%, 20 \%$ dan $40 \%$.
\end{abstract}

Kata kunci: Melastoma malabathricum L., Antibakteri, Salmonellosis. 


\section{LATAR BELAKANG}

Melastoma malabathricum L. termasuk famili Melastomataceae adalah salah satu tumbuhan berkhasiat obat yang banyak dimanfaatkan masyarakat di Asia. Masyarakat di Indonesia dan Malaysia, menggunakan daun dan akar dari tumbuhan ini untuk mengobati penyakit diare, mengatasi gangguan pencernaan, disentri, keputihan (leukorea), wasir, luka, sakit gigi dan sariawan. Masyarakat di Kabupaten Sintang, Kalimantan Barat, juga menggunakan daun ini sebagai obat penurun demam dengan cara meminum air rebusan daun (Van Valkenburg and Bunyapraphatsara 2002). Masyarakat di Desa Lero Kecamatan Sindue, Sulawesi Tengah memanfaatkan tumbuhan ini secara tradisional sebagai obat diare terutama bagian daunnya.

Beberapa penelitian telah dilakukan pada tumbuhan $M$. malabathricum $\mathrm{L}$. salah satunya oleh Retnaningtyas (2008), yang menguraikan bahwa ekstrak etanol daun $M$. malabathricum L. dengan konsentrasi 10-100\% memiliki aktivitas antibakteri terhadap Staphylococcus aureus, serta memiliki aktivitas penghambatan yang kuat hingga sangat kuat terhadap pertumbuhan beberapa bakteri lain seperti Bacillus subtilis, Bacillus cereus dan Escherichia coli. Sudarmono (2010), juga menunjukkan adanya potensi daun M. malabathricum $\mathrm{L}$. sebagai antibakteri. Daun $M$. malabathricum L. ini telah digunakan untuk mengobati penyakit gangguan pencernaan (Van Valkenburg and Bunyapraphatsara 2002), tetapi belum ada laporan bahwa tumbuhan ini dapat digunakan sebagai bahan antibakteri penyebab Salmonellosis yang ditandai dengan demam tifoid.

Demam tifoid adalah penyakit infeksi akut sistemik dan endemis di Indonesia yang disebabkan oleh bakteri Salmonella typhi. Gejala yang ditimbulkan diantaranya adalah diare yang bercampur darah dan mukosa, mulas dan kejang perut, demam sampai $40^{\circ} \mathrm{C}$ dan kadang disertai muntah. Menurut WHO Demam tifoid masih merupakan masalah besar kesehatan khususnya di berbagai negara sedang berkembang (Triatmodjo, 1998).

Patogenesis Salmonella utamanya diatasi dengan pengobatan antibiotik. Antibiotik yang digunakan untuk mengatasi demam tifoid selama ini adalah Kloramfenikol dan Amoksilin (Pelczar and Chan, 1988). Namun tingginya harga antibiotik menjadi kendala utama bagi masyarakat yang berekonomi lemah untuk mengobati penyakit infeksi ini. Disamping itu, penggunaan antibiotika yang tidak benar dapat menyebabkan resistensi. Berbagai upaya mencari pengobatan alternatif terus ditingkatkan, 
salah satunya dengan mengembangkan obat tradisional.

Berdasarkan uraian di atas, maka perlu dilakukan penelitian mengenai Potensi Tumbuhan Melastoma malabathricum L. Sebagai Bahan Antibakteri Salmonellosis sehingga dapat dijadikan sebagai acuan pengobatan herbal untuk pengobatan penyakit yang disebabkan oleh bakteri.

Tujuan dari penelitian ini yaitu untuk mendeskripsikan morfologi tumbuhan M. malabathricum L. yang ada di Sulawesi Tengah, mengetahui keefektifan ekstrak daun $M$ malabathricum L. dalam menghambat pertumbuhan bakteri $S$. typhi serta mengetahui jumlah konsentrasi ekstrak daun $M$. malabathricum L. yang efektif dalam menghambat pertumbuhan bakteri S. typhi.

\section{BAHAN DAN METODE}

Penelitian dilaksanakan pada bulan September sampai Desember 2016, di Laboratorium Bioteknologi Jurusan Biologi Fakultas Matematika dan Ilmu Pengetahuan Alam Universitas Tadulako dan Laboratorium Agroteknologi Fakultas Pertanian Universitas Tadulako.

Metode yang digunakan yaitu metode survei untuk memperoleh tumbuhan, metode deskriptif untuk determinasi tumbuhan dan metode eksperimental untuk melihat kemampuan antibakteri yang disusun berdasarkan model Rancangan Acak Lengkap (RAL) terdiri dari 6 perlakuan mengacu dari cara kerja Retnaningtyas (2008), yaitu konsentrasi 10\%, 20\%, 40\%, 60\%, kontrol positif yang menggunakan antibiotik Amoxicillin 2\% dan kontrol negatif menggunakan Na-CMC 1\%. Perlakuan diulang sebanyak 3 kali pengulangan.

Tahap penelitian yang dilakukan adalah sebagai berikut:

1. Pengambilan Sampel

Pengambilan sampel daun $M$. malabathricum L. diperoleh dari Desa Lero, Kecamatan Sindue.

2. Deskripsi Sampel

Sampel daun $M$. malabathricum L. yang berasal dari Desa Lero, Kecamatan Sindue dideskripsikan berdasarkan karakteristik pada buku Van Valkenburg and Bunyapraphatsara (2002).

3. Pembuatan Ekstrak

$$
\text { Ekstraksi Daun } M \text {. }
$$

malabathricum L. dilakukan menggunakan metode maserasi, karena struktur sampel daun yang cukup kecil dan lunak. Daun tua $M$. malabathricum L. ditimbang sebanyak 3.100 g. Setelah itu sampel daun disortasi basah, kemudian dicuci dengan air mengalir. Daun tersebut 
kemudian dirajang menjadi ukuran yang lebih kecil dan dikeringkan dengan menggunakan oven selama 8 jam. Menurut Ajizah (2004) pengeringan dilakukan selama 8 jam pada suhu $40^{\circ} \mathrm{C}$ untuk memperoleh kadar air kurang lebih $5 \%$. Daun yang telah kering dihaluskan menggunakan blender dan diayak menggunakan mess 40. Selanjutnya ditimbang kembali sehingga diperoleh berat kering dari sampel tersebut yaitu $2.350 \mathrm{~g}$. Serbuk tersebut direndam dengan menggunakan pelarut etanol $96 \%$ sebanyak 2 L selama 5 hari sambil diaduk sesekali. Selanjutnya hasil rendaman disaring dengan menggunakan kertas saring dan dilakukan pemisahan antara pelarut dan senyawa aktif hasil ekstraksi dengan menggunakan alat rotary evapouration hingga diperoleh ekstrak kental daun M. malabathricum L.

4. Pembuatan Stok Konsentrasi Ekstrak

Pembuatan stok konsentrasi ekstrak dengan cara pengenceran konsentrasi ekstrak menggunakan pelarut Na-CMC $1 \%$ yang terdiri dari masing-masing konsentrasi ekstrak $10 \%, \quad 20 \%, \quad 40 \%$ dan $60 \%$ (Retnaningtyas, 2008). Setiap seri konsentrasi dibuat $10 \mathrm{ml}$ stok dengan jumlah ekstrak masing-masing secara berturut-turut sebesar $1 \mathrm{~g}, 2 \mathrm{~g}, 4 \mathrm{~g}$, dan $6 \mathrm{~g}$.

5. Pembuatan Suspensi Bakteri Salmonella typhi

Bakteri yang akan digunakan dikulturisasi, yaitu dengan cara memindahkan bakteri dari medium yang lama ke medium yang baru yakni dari medium NA miring yang diambil 1 ose kemudian disuspensikan ke dalam medium LB sebagai media pemupuk/penyubur yang berguna untuk pertumbuhan bakteri, lalu diinkubasikan selama 24 jam pada suhu $37^{\circ} \mathrm{C}$, setelah itu dilakukan pengenceran bertingkat dengan menggunakan larutan $\mathrm{NaCl}$ fisiologi $0,9 \%$.

6. Uji Daya Hambat

Uji aktivitas antibakteri ekstrak daun Melastoma malabathricum L. dilakukan dengan menggunakan metode sumur (Cup-Plate Technique) sesuai dengan cara kerja Kirby (1966), dengan konsentrasi 10\%, 20\%, 40\%, $60 \%$ dan kontrol positif yang menggunakan antibiotik Amoxicillin $2 \%$ serta kontrol negatif menggunakan $\mathrm{Na}-\mathrm{CMC} 1 \%$.

Suspensi bakteri S. typhi dari pengenceran $10^{6}$ diambil sebanyak 1 ml dan dimasukkan ke dalam cawan petri steril, setelah itu sebanyak $20 \mathrm{ml}$ media SSA (Salmonella- Shigella 
Agar) dituangkan ke dalam cawan petri yang telah terisi dengan suspensi bakteri $S$. typhi dan di homogenkan kemudian dibiarkan hingga memadat. Setelah medium padat, dilakukan uji ekstrak daun dengan metode sumur. Media yang telah padat dilubangi menyerupai sumur dengan diameter 6 mm menggunakan tabung durham dan pinset. Ekstrak daun dimasukkan ke dalam lubang sebanyak $100 \mu \mathrm{l}$ dengan beberapa konsentrasi yaitu 10\%, 20\%, $40 \%$ dan $60 \%$ pada tiap cawan yang berbeda. Kemudian di inkubasi selama 24 jam pada suhu $37^{\circ} \mathrm{C}$. Cawan petri yang dimasukkan kedalam inkubator harus dengan hati-hati. Semua perlakuan yang dilakukan dalam keadaan aseptis (Kirby, 1966).

7. Pengamatan Zona Hambat

Pengamatan zona hambat ekstrak daun Melastoma malabathricum L. terhadap pertumbuhan bakteri Salmonella typhi pada masing-masing cawan petri dilakukan setelah masa inkubasi. Pengukuran zona hambat dilakukan dengan cara mengukur diameter zona hambat yang terbentuk dari masing-masing perlakuan dengan menggunakan jangka sorong. Pengukuran dilakukan pada tiap cawan yang masing-masing dari pengujian ekstrak daun terdapat konsentrasi yaitu
$10 \%, 20 \%, 40 \%$ dan $60 \%$ dengan tambahan kontrol positif.

\section{Analisis Data}

Data kuantitatif yang diperoleh dari pengukuran, kemudian dianalisis secara statistik menggunakan software (Statistical Product Services Solution) SPSS versi 21 "One Way Anova”.

Bilamana terjadi perbedaan yang nyata antar perlakuan pada taraf uji 5\% $(\mathrm{P} \leq 0,05)$ maka akan dilakukan uji lanjut Duncan's Multiple Range Test (DMRT).

\section{HASIL}

\section{Deskripsi Tumbuhan}

Tumbuhan Melastoma malabathricum L. yang terdapat di Desa Lero, Kecamatan Sindue dideskripsi berdasarkan karakteristik pada Van Valkenburg and Bunyapraphatsara (2002) dengan mengamati bagian morfologi termasuk ukuran organ tumbuhan. tumbuhan. Hasil deskripsi disajikan pada Tabel 1

\section{Uji Daya Hambat}

Pengamatan terhadap diameter zona daya hambat dari masing-masing konsentrasi ekstrak diukur dengan menggunakan jangka sorong. Hasil pengukuran zona hambat disajikan pada Tabel 1 
Tabel 1 Hasil Rata-rata zona daya hambat ekstrak terhadap pertumbuhan bakteri Salmonella typhi

\begin{tabular}{|c|c|c|c|c|c|}
\hline \multirow[t]{2}{*}{ Konsentrasi } & \multicolumn{3}{|c|}{$\begin{array}{c}\text { Pengamatan Zona } \\
\text { Hambat Tiap } \\
\text { Ulangan (mm) }\end{array}$} & \multirow[t]{2}{*}{ Jumlah } & \multirow[t]{2}{*}{$\begin{array}{l}\text { Rata- } \\
\text { rata }\end{array}$} \\
\hline & U1 & U2 & U3 & & \\
\hline $\begin{array}{c}\text { Kontrol } \\
\text { negatif (Na- } \\
\text { CMC 1\%) }\end{array}$ & 0 & 0 & 0 & 0 & 0 \\
\hline $10 \%$ & 11 & 12 & 11 & 34 & 11,3 \\
\hline $20 \%$ & 12 & 14 & 12 & 38 & 12,6 \\
\hline $40 \%$ & 12 & 16 & 15 & 43 & 14,3 \\
\hline $60 \%$ & 18 & 20 & 24 & 62 & 20,6 \\
\hline $\begin{array}{c}\text { Kontrol } \\
\text { positif } \\
\text { (Amoxicillin } \\
2 \% \text { ) }\end{array}$ & 27 & 28 & 26 & 81 & 27 \\
\hline
\end{tabular}

Morfologi tumbuhan M. Malaba-thricum L. disajikan pada Gambar 1.

\begin{tabular}{|c|c|c|c|c|}
\hline $\begin{array}{l}\text { Nama } \\
\text { Lokal }\end{array}$ & Nama Ilmiah & Morfologi & Karakter & $\begin{array}{l}\text { Karakter menurut Van } \\
\text { Valkenburg and } \\
\text { Bunyapraphatsara (2002) }\end{array}$ \\
\hline \multirow{29}{*}{ Lalumpa } & \multirow{29}{*}{$\begin{array}{l}\text { Melastoma } \\
\text { malabathricum } \\
\text { L. }\end{array}$} & Batang (caulis) & & \\
\hline & & Tinggi batang & $1-2 \mathrm{~m}$ & $1-3 \mathrm{~m}$ \\
\hline & & Arah tumbuh batang & Tegak lurus (erectus) & Tegak lurus (erectus) \\
\hline & & Bentuk batang & Bulat (teres) & Bulat (teres) \\
\hline & & Permukaan batang & Kasar & Kasar \\
\hline & & Warna batang & Coklat & Coklat \\
\hline & & Percabangan & Simpodial & Simpodial \\
\hline & & \multicolumn{3}{|l|}{ Daun (folium) } \\
\hline & & Struktur daun & Tunggal (simplex) & Tunggal (simplex) \\
\hline & & Duduk daun & $\begin{array}{l}\text { Berhadapan bersilang } \\
\text { (folia opposita) }\end{array}$ & $\begin{array}{l}\text { Berhadapan bersilang } \\
\text { (folia opposita) }\end{array}$ \\
\hline & & Warna daun & Hijau & Hijau \\
\hline & & Bentuk daun & Jorong (ovalis) & Jorong (ovalis) \\
\hline & & Panjang daun & $2-5 \mathrm{~cm}$ & $4-6 \mathrm{~cm}$ \\
\hline & & Lebar daun & $1,5-3,5 \mathrm{~cm}$ & $2-4 \mathrm{~cm}$ \\
\hline & & Ujung daun & Runcing (acutus) & Runcing (acutus) \\
\hline & & Tepi daun & Rata (integer) & Rata (integer) \\
\hline & & Permukaan daun & Berbulu halus (hispidus) & Berbulu halus (hispidus) \\
\hline & & Pertulangan & Melengkung (cervinervis) & Melengkung (cervinervis) \\
\hline & & Pangkal daun & Membulat (rotundatus) & Membulat (rotundatus) \\
\hline & & Tangkai daun & $5-10 \mathrm{~mm}$ & $5-12 \mathrm{~mm}$ \\
\hline & & \multicolumn{3}{|l|}{ Bunga (flos) } \\
\hline & & Letak & Flos terminalis & Flos terminalis \\
\hline & & Tipe & $\begin{array}{l}\text { Majemuk terbatas } \\
\text { (inflorescentia centrifuga) }\end{array}$ & $\begin{array}{l}\text { Majemuk terbatas } \\
\text { (inflorescentia centrifuga) }\end{array}$ \\
\hline & & Mahkota & $\begin{array}{l}\text { Berjumlah } 5 \text {, Berlekatan, } \\
\text { warna ungu }\end{array}$ & $\begin{array}{l}\text { Berjumlah } 5 \text {, Berlekatan, } \\
\text { warna ungu }\end{array}$ \\
\hline & & Benang sari & $\begin{array}{l}\text { Berjumlah 6-12, warna } \\
\text { merah muda }\end{array}$ & $\begin{array}{l}\text { Berjumlah 6-12, warna } \\
\text { merah muda }\end{array}$ \\
\hline & & Putik & Memiliki 1 putik & Memiliki 1 putik \\
\hline & & \multicolumn{3}{|l|}{ Buah (fructus) } \\
\hline & & Tipe & Buni (bacca) & Buni (bacca) \\
\hline & & Warna buah & Coklat & Coklat \\
\hline
\end{tabular}




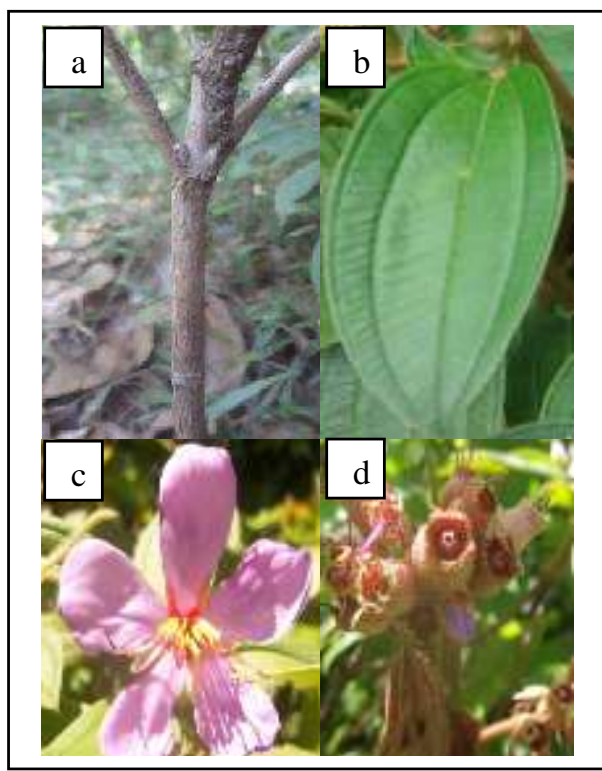

Gambar 1 Tumbuhan M. malabathricum L. di Desa Lero, Kecamatan Sindue. (a) Batang (caulis), (b) Daun (folium), (c) Bunga (flos), (d) Buah (fructus).

Salah satu zona daya hambat yang terbentuk, disajikan pada Gambar 2

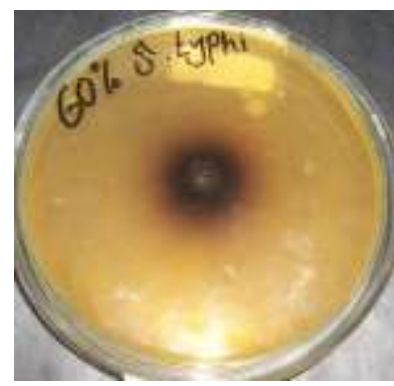

Gambar 2. Zona daya hambat yang terbentuk di sekitar sumur pada konsentrasi $60 \%$ terhadap bakteri $S$. typhi

Berdasarkan uji statistik dengan menggunakan one way anova maka diperoleh grafik dari hasil uji daya hambat ekstrak daun M. malabathricum L. terhadap bakteri S. typhi yang disajikan pada Gambar 3

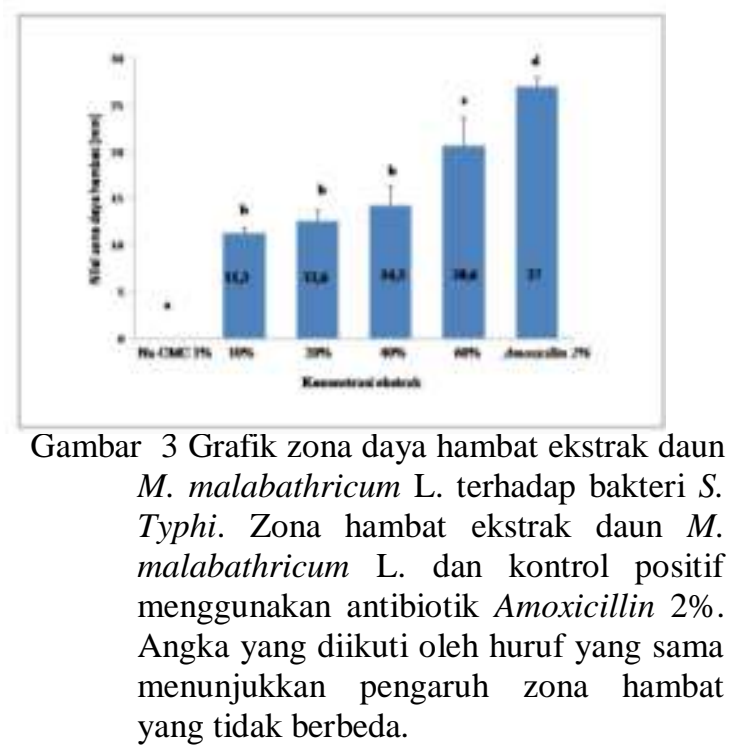

\section{Pembahasan}

Deskripsi morfologi tumbuhan Melastoma malabatricum L. yang berasal dari Desa Lero, Kecamatan Sindue, merupakan tumbuhan yang sejenis dengan tumbuhan yang dideskripsikan oleh Van Valkenburg and Bunyapraphatsara (2002) dengan perbedaan morfologi pada tumbuhan $M$. malabatricum L. meliputi tinggi batang dan ukuran daun, dimana pada tinggi batang tumbuhan $M$. malabatricum L. yaitu 1-2 $\mathrm{m}$, daun memiliki panjang 2-5 $\mathrm{cm}$, lebar 1,5-3,5 $\mathrm{cm}$ dan panjang tangkai daun 5-10 mm, namun masih lebih kecil ukurannya dibandingkan dengan yang dideskripsikan oleh Van Valkenburg and Bunyapraphatsara (2002) yaitu tinggi batang tumbuhan $M$. malabatricum L. adalah 1-3 m, serta daun memiliki panjang 4-6 cm, lebar 2-4 cm dan panjang tangkai daun 5-12 $\mathrm{mm}$.

\section{Potensi Tumbuhan Melastoma malabathricum L. Sebagai Bahan Antibakteri Salmonellosis}


Pemberian ekstrak daun tumbuhan M. malabathricum L. dengan berbagai konsentrasi $10 \%, 20 \%, 40 \%, 60 \%$ dan kontrol positif menggunakan Amoxicillin $2 \%$, menunjukkan adanya zona daya hambat ekstrak terhadap pertumbuhan bakteri S. typhi, sedangkan pada kontrol negatif tidak menunjukkan adanya zona daya hambat. Hal tersebut dikarenakan pemberian larutan $\mathrm{Na}-\mathrm{CMC} 1 \%$ tanpa campuran ekstrak yakni tidak memiliki aktivitas antibakteri.

Zona daya hambat yang lebih besar terdapat pada perlakuan dengan pemberian ekstrak daun $M$. malabathricum L. pada konsentrasi $60 \%$ menghasilkan zona hambat rata-rata sebesar 20,6 mm, lebih besar dibandingkan dengan pemberian konsentrasi lainnya (Gambar 2). Namun demikian zona daya hambat tersebut masih lebih kecil dibandingkan dengan zona daya hambat yang terbentuk pada kontrol positif (Amoxicillin 2\%) yaitu rata-rata sebesar $27 \mathrm{~mm}$. Untuk daya hambat paling kecil terdapat pada perlakuan dengan pemberian ekstrak daun paling rendah (10\%) yaitu rata-rata sebesar 11,3 mm. Amoxicillin merupakan antibakteri spektrum luas yang bersifat bakterisid dan efektif terhadap sebagian bakteri Gram negatif dan beberapa Gram positif yang patogenik. Salmonella typhi merupakan salah satu bakteri patogenik yang sensitif terhadap amoxicillin (Werckenthin et al., 2001).

Menurut Banso (2009), berdasarkan zona daya hambat yang terbentuk, zona daya hambat dikelompokkan menjadi 4 kelompok yaitu sangat kuat bila zona hambat $>20 \mathrm{~mm}$, kuat $10-20 \mathrm{~mm}$, sedang 5-10 mm dan lemah $<5 \mathrm{~mm}$. Kontrol positif tergolong dalam sediaan yang memberikan zona hambat sangat kuat terhadap pertumbuhan S. typhi yaitu 27 mm, sedangkan ekstrak daun tumbuhan M. malabathricum L. 10\%, 20\%, 40\% dan $60 \%$ termasuk dalam sediaan yang memberikan zona hambat kuat.

Hasil pengujian menunjukkan bahwa dari berbagai konsentrasi memberikan perbedaan diameter zona hambat yang bervariasi. Perbedaan besar diameter zona hambat ini kemungkinan disebabkan adanya perbedaan kecepatan ekstrak berdifusi ke medium agar. Faktor lain yang menyebabkan perbedaan diameter zona hambat dari ekstrak tersebut adalah perbedaan konsentrasi senyawa aktif yang terdapat pada ekstrak. Sesuai dengan pendapat Prescott (2005), bahwa ukuran dari zona hambat dipengaruhi oleh beberapa hal, seperti tingkat sensitifitas dari organisme uji, kecepatan difusi dari senyawa antibakteri dan konsentrasi senyawa antibakteri.

Uji lanjut yang digunakan adalah uji Duncan. Uji Duncan digunakan untuk 
melihat perlakuan mana yang memiliki efek yang sama atau berbeda dan efek yang terkecil sampai efek yang terbesar antara satu dengan lainnya (Simanjuntak, 2008). Berdasarkan uji lanjut Duncan perlakuan dengan konsentrasi 10\%, 20\% dan $40 \%$ tidak memiliki perbedaan nilai yang signifikan. Sedangkan perlakuan konsentasi 40\%, 60\% dan kontrol positif terdapat perbedaan yang signifikan terhadap konsentrasi ekstrak yang lain. Secara statistik hal ini berarti konsentrasi ekstrak tersebut telah menunjukkan efek yang berbeda nyata dalam menghambat pertumbuhan bakteri S. typhi. Salah satu fungsi analisis statistik ialah untuk melihat ada tidaknya perbedaan antara perlakuan yang satu dengan kelompok yang lainnya atas obyek yang diteliti.

Ekstrak daun M. malabathricum L. membentuk zona hambat yang paling baik yakni pada konsentrasi $60 \%$ dan zona hambat terkecil pada pemberian ekstrak 10\%. Hal ini menunjukkan bahwa semakin tinggi konsentrasi suatu ekstrak maka semakin cepat sel mikroorganisme terbunuh atau terhambat pertumbuhannya (Pelczar dan Chan, 1988). Menurut Ajizah (2004), selain faktor konsentrasi, jenis bahan antimikroba juga menentukan kemampuan menghambat pertumbuhan bakteri. Hal tersebut diduga juga berkaitan dengan kandungan senyawa antibakteri pada ekstrak daun $M$. malabathricum L. seperti saponin, flavonoid dan tanin (Funatogawa et al., 2004).

Berdasar hasil dan pembahasan, dapat disimpulkan, bahwa Tumbuhan $M$. malabathricum L. yang berasal dari Desa Lero, Kecamatan Sindue, merupakan tumbuhan yang sejenis dengan tumbuhan yang dideskripsikan oleh Van Valkenburg and Bunyapraphatsara (2002). Daun $M$. malabathricum L. memiliki kemampuan menghambat bakteri $S$. typhi dengan konsentrasi ekstrak daun $M$. malabathricum L. yang paling efektif dalam menghambat bakteri $S$. typhi yaitu $60 \%$.

\section{DAFTAR PUSTAKA}

Ajizah. (2004). Sensitivikasi Salmonella thypimurium terhadap Ekstrak Daun Psidium guajava L. Bioscientiae (1). Banjarmasin: Universitas Lambung Mangkurat.

Banso. (2009). Phytochemical and Antibacterial Investigation of Bark Extracts of Acacia nilotica. J. of Medicinal Plants Research, 3(2), 082-085.

Funatogawa, K., Hayashi, S., and Shimomura, H. (2004). Antibacterial Activity of Hydrolizable Tannins from Medicinal Plants against Helicobacter Pylori. J. Microbiol Immunol, 48(4), 251-261.

Kirby, B. (1966). Disc Plate Method of Microbiological Antibiotic Assay. American Society for Microbiology, 22(4), 659-663. 
Pelczar, M. J., and Chan, E. C. (1988). Dasar-Dasar Mikrobiologi Jilid 2. Jakarta: UI Press.

Prescott, M. (2005). Microbiology, New York: Mc. Grow - Hill.

Retnaningtyas, E., dan Mulyani, S. (2008). Aktivitas Antibakteri Ekstrak Metanol dan Fraksi nHeksan: Kloroform: Asam Asetat (7:2:2) dari Daun Melastoma Candidum D. Don terhadap Pertumbuhan Salmonella Typhi. Di dalam: Teknologi Informatika dalam Mendukung Perkembangan Research dan Pembelajaran Biologi. Prosiding Seminar Nasional Pendidikan Biologi FKIP. Surakarta: LPPM UNS. http://eprints.uns.ac.id/1946/1/1254 28291554079654.pdf.

Simanjuntak, R. (2008). Demam Typoid. Cermin Dunia Kedokteran, 3 (5253).

Sudarmono, P. (2010) Kebijakan pemakaian Antibiotika dalam kaitannya dengan Resistensi Kuman. Majalah Kedokteran Indonesia, 22 (21-32).

Triatmodjo, P. (1998). Besarnya Kasus Demam Tifoid di Indonesia dan Pola Resisten Salmonella typhi terhadap Antibiotika. Majalah Kesehatan Masyarakat Indonesia, 6 (261-263).

Van Valkenburg, J. L. C. H., and Bunyapraphatsara, N. (2002). Medicinal and Poisonous Plants 2. J. Plant Resources Of South East Asia, 12(2), 365-366.

Werckenthin, C., Cardoso, M., and Schwarz, S. (2001). Antimicrobial Resistance in Sthapylococci from Animals with Particular Reference to Bovine $S$. aureus. Porcino S. hycus Canine S. Intermediu. J. Vet. Res ,3(2), 341-362 